\title{
Strategi Pemasaran Musisi Indie dalam Industri Musik Indonesia (Analisis terhadap Adhitia Sofyan)
}

\author{
Godam Bingar Jati, Farid Rusdi \\ godambj@gmail.com,farid@fikom.untar.ac.id
}

Fakultas Ilmu Komunikasi Universitas Tarumanagara

\begin{abstract}
This research is the author of a thorough research to see the marketing strategies used by indie musicians in the music industry. The purpose of this research is to see what marketing communication strategy is used by Adhitia Sofyan Team in conducting marketing activities. With today's technological developments, artists can use various kinds of computer software to record their work and market it through various social media online. An independent label, also known as an indie label, is a record label company that can market, fund, and publish artists and their work, funded independently. By analyzing a person's research subject (Adhitia Sofyan). The research method that I use here is to use qualitative methods. The research technique uses analytical techniques. The data technique used observation and interview techniques. The interview was conducted with one of the indie staff management (Rendy Kopoy) as the manager of Adhitia Sofyan. He was also the manager of a duo Endah and Resha before becoming manager of Adhitia Sofyan. From this research, it is hoped that it can add information about the indie music industry in Indonesia, as well as knowledge about integrated marketing communications.
\end{abstract}

Keywords: adhitia sofyan, indie musicians, integrated marketing communication

\begin{abstract}
Abstrak
Penelitian ini penulis teliti untuk mengetahui Strategi pemasaran yang digunakan oleh musisi indie dalam industri musik. Tujuan dari penelitian ini adalah untuk mengetahui strategi komunikasi pemasaran apakah yang digunakan oleh Tim Adhitia Sofyan dalam melakukan kegiatan pemasaran. Dengan adanya perkembangan teknologi di masa kini, artis dapat menggunakan berbagai macam software komputer untuk merekam karyanya dan memasarkannya melalui berbagai media sosial secara online. Label independen, juga dikenal sebagai label indie, adalah perusahaan label rekaman yang dapat memasarkan, membiayai, dan mempublikasikan artis dan karyanya, didanai secara independen. Dengan menganalisis subjek penelitian musisi indie (Adhitia Sofyan). Metode penelitian yang penulis pakai disini adalah dengan menggunakan metode kualitatif. Teknik penelitian memakai teknik analisis. Teknik pengumpulan data menggunakan yaitu teknik observasi dan juga wawancara. Wawancara dilakukan dengan salah satu manajemen musisi indie (Rendy Kopoy) selaku manajer Adhitia Sofyan. Ia juga pernah menjadi manajer salah satu duo Endah and Resha sebelum menjadi manajer Adhitia Sofyan. Dari penelitian ini, diharapkan dapat menambah informasi tentang industri musik indie di Indonesia, serta pengetahuan tentang komunikasi pemasaran terpadu.
\end{abstract}

Kata Kunci: adhitia sofyan, komunikasi pemasaran terpadu, musisi indie

\section{Pendahuluan}

Musik adalah salah satu solusi hiburan bagi hampir setiap orang. Bahkan musik termasuk wadah universal yang menyampaikan komunikasi dalam bentuk sebuah 
lagu. Perkembangan musik di Indonesia kini telah menjadi salah satu hal yang menarik untuk dibahas, karena industri musik di indonesia kini memiliki banyak perkembangan, dari munculnya banyak musisi dan berbagai macam genre serta aliran musik atau band. Antusiasme khalayak pada musik sangat dapat dilihat di era sekarang ini, contohnya dalam tingginya minat masyarakat dalam menghadiri event atau acara musik. Tidak hanya sampai membuat karya akan tetapi untuk berhasil di dunia industri musik harus didukung dengan prasarana, strategi pemasaran supaya karya musik yang sudah diproduksi bisa dinikmati oleh masyarakat (Iswandi, 2015).

Kini banyak musisi yang telah memilih memproduksi dan mempromosikan karya mereka melalui jalur indie. Sementara Indie (singkatan dari independen), menurut Kamus Besar Bahasa Indonesia (KBBI) dapat berarti bebas, merdeka atau berdiri sendiri. Dikaitkan dengan sebuah band, maka band indie adalah band yang mandiri, berdiri sendiri, dari segi pendanaan semua pengeluaran, mulai produksi, pemasaran sampai distribusinya.

\section{Metode Penelitian}

Penelitian yang dilakukan oleh penulis ini menggunakan metode penelitian kualitatif yaitu bersifat deskriptif serta lebih cenderung menggunakan analisis. Sudut pandang dari objek penelitian sangat ditonjolkan dalam karya ilmiah ini. Untuk mendukung hasil penelitian yang dilakukan dengan cara pengumpulan data, penulis menggunakan beberapa metode penelitian dalam melakukan pengumpulan data, yaitu observasi dan wawancara.

Observasi adalah pengamatan serta mencatat proses pada suatu fenomena fenomena yang memiliki unsur dalam objek penelitian. Dalam pengertian lain disebutkan bahwa metode observasi atau disebut dengan pengamatan adalah kegiatan pemusatan perhatian terhadap suatu obyek dengan menggunakan seluruh panca indra. Dalam hal ini penulis melakukan observasi dengan mengamati Musisi Indie (Adhitia Sofyan) di industri musik Indonesia sekarang ini melalui media sosial atau media massa (radio dan televisi).

Wawancara adalah salah satu metode pengumpulan data pada penelitian kualitatif. Secara sederhana dapat dikatakan bahwa wawancara (interview) adalah suatu proses interaksi antara pewawancara dan narasumber atau orang yang di wawancarai melalui komunikasi langsung. Dalam hal ini penulis melakukan wawancara kepada salah satu manajemen dari Adhitia Sofyan.

Analisis data kualitatif dilakukan apabila data empiris yang diperoleh adalah data kualitatif berupa kumpulan berwujud kata-kata dan bukan rangkaian angka serta tidak dapat disusun dalam kategori-kategori/struktur klasifikasi. Secara sederhana dapat dikatakan bahwa wawancara (interview) adalah suatu proses interaksi antara pewawancara dan narasumber atau orang yang di wawancarai melalui komunikasi langsung. Dalam hal ini penulis melakukan wawancara kepada salah satu manajemen dari Adhitia Sofyan.

\section{Hasil Temuan dan Diskusi}

\section{Segmentasi, Targeting dan Positioning (STP) Adhitia Sofyan}

Segmentasi Segmentasi pendengar dari Adhitia Sofyan diperuntukan untuk orang-orang yang sedang merasakan kesedihan atau mengalami masalah dalam kehidupannya. Data ini didapatkan melalui wawancara yang telah dilakukan oleh 
peneliti dengan manajer dari tim manajemen Adhitia Sofyan. Melalui wawancara yang dilakukan oleh peneliti, narasumber mengatakan "hal pertama dan yang utama dari tim adhitia sofyan, dalam melakukan pemasaran atau branding adalah kita harus tau STP nya. STP itu segmentasi, targeting, positioning. Disini kita sangat memperhatikan hal tersebut. Dimana kami telah mengetahui siapa saja target pendengar yang perlu kita tuju."

Hal itu dikarenakan pada saat tahun 2009, Adhitia Sofyan menrilis lagu - lagu yang melow dan lirik yang menggambarkan kesedihan seseorang menjadi musik yang memberikan vibes semangat dan memotivasi dalam kehidupan sehari - hari. Dan hal itu tidak berhasil. Dalam album "Silver Painted Radiance" pada tahun 2016, karya tersebut bisa disebut gagal. Karena memiliki biaya produksi yang cukup mahal serta tidak adanya feedback yang baik dari pendengar.

Adhitia Sofyan juga dikenal sebagai songwriter musik galau, di mana lagu - lagu yang diciptakannya menggambarkan kesedihan. Menurut peneliti, hali ini dipengaruhi oleh awal karir dari Adhitia Sofyan itu sendiri. Dimana Adhitia Sofyan naik daun ketika merilis salah satu lagu "Adelaide Sky". Respon dari pendengar dalam lagu itu sangat positif, juga memberikan julukan musisi atau songwriter galau.

Hal ini berkaitan dengan teori tentang segmentasi, targeting dan positioning yang dikatakan oleh Kotler (2005:339). Menurut Kotler seluruh strategi pemasaran harus dibangun berdasarkan tiga langkah utama dalam pemasaran bersasaran yaitu STPSegmentation, Targeting dan Positioning. Segmentasi pasar yaitu usaha pemisahan pasar pada kelompok-kelompok pembeli menurut jenisjenis produk tertentu dan yang memerlukan bauran pemasaran tersendiri. Menurut Kotler (dalam Basu, Swastha, dan, Irawan, 2001) pasar sasaran adalah tindakan mengevaluasi dan menseleksi satu atau lebih segmen pasar yang hendak dimasuki.

\section{Komunikasi Pemasaran Terpadu (Integrated Marketing Communication) Adhitia Sofyan}

Dalam Komunikasi Pemasaran terpadu terdapat enam dimensi utama, dan dimensi tersebut juga berkaitan dengan penelitian ini, yaitu:

\section{A. Penjualan perorangan (Personal Selling)}

Tim dari Adhitia Sofyan melakukan personal selling dengan cara mengajak pendengar untuk datang ke salah satu event kecil yang diadakan di earhouse cafe di jakarta selatan. Pada acara tersebut, pendengar dapat melihat dan mendengarkan Adhitia Sofyan secara langsung tanpa adanya biaya.

\section{B. Iklan (Advertising)}

Iklan yang dibuat oleh tim dari Adhitia Sofyan dalam bentuk konten atau digital ads yang diinformasikan melalui social media atau internet. Iklan yang dibuat bukan hanya untuk menginformasikan adanya konser, tetapi juga untuk menginformasikan karya-karya terbaru yang akan dirilis oleh musisi. Selain itu, tim Adhitia Sofyan juga memasang iklan melalui music app seperti Spotify, Joox, Apple Music.

\section{Promosi Penjualan (Sales Promotion)}

Dalam hal ini, Tim dari Adhitia Sofyan melakukannya dengan cara membuat konten iklan tentang informasi adanya konser tunggal yang akan diadakan kedepannya dengan tiket yang terbatas. Sehingga terjadinya aksi pembelian yang cepat dari para pendengar. 
Godam Bingar Jati, Farid Rusdi: Strategi Pemasaran Musisi Indie dalam Industri Musik Indonesia (Analisis terhadap Adhitia Sofyan)

\section{Pemasaran Sponsorship (Sponsorship Marketing)}

Beberapa lagu yang diciptakan dan dinyanyikan oleh Adhitia Sofyan juga tidak jarang menjadi soundtrack sebuah film ataupun Short Movie. Beberapa film atau short movie yang menjadikan musik Adhitia Sofyan sebagai Soundtrack adalah "Kambing Jantan The Movie" dan "Sore". Sehingga pemasaran sponsorship juga berkaitan dengan penelitian ini.

\section{E. Publisitas (Publicity)}

Publisitas sangat erat dengan komunikasi massa; Bentuk-bentuk ini dimuat dalam media. Adhitia Sofyan dipromosikan oleh beberapa media. Bukan hanya BukaLapak, tetapi Adhitia Sofyan juga sering masuk dalam berita di banyak media musik. Dari informasi yang disampaikan melalui berita, itu menjadi sebuah keuntungan bagi Adhitia Sofyan dalam melakukan branding. Karena di sisi lain, Adhitia Sofyan tidak perlu mengeluarkan budget pemasaran ataupun branding dalam mempromosikan dirinya.

\section{F. Komunikasi di Tempat Pembelian (Point-of-Purchase Communication)}

Menggunakan poster, tanda, atau iklan yang didesain untuk mempengaruhi keputusan pembelian. Adhitia Sofyan memiliki keunikan dalam design cover albumnya. Itu menjadi ketertarikan sendiri bagi pendengar untuk membeli karya fisik ataupun melalui digital. Karena disisi lain, Adhitia Sofyan memiliki design cover yang berbeda dengan musisi - musisi indie lainnya.

\section{Media Baru (New Media)}

Simpson (2006), mengkategorikan bermacan inkarnasi dari industri musik sebagai berikut: Era mekanikal (pianolas dan lembaran musik), Era elektronik (mikrofon,format produk rekaman analog), dan Era digit al (CD, Download, mengakses musik secara online). Promosi dan branding yang dilakukan oleh Adhitia Sofyan sebagian besar ada di media sosial. Sekarang banyak musisi yangmelakukan branding atau pemasaran melalui media sosial, dikarekan kemudahan mengakses internet dan juga cangkupan target pasar yang juga luas. Hal ini lah yang membuat Tim dari Adhitia Sofyan melakukan branding melalui digital.

Livingstone (dalam McQuail, 2011) mengatakan bahwa apa yang baru mengenai internet adalah kombinasi dari interaktivitas dengan ciri yang inovatif bagi komunikasi massa-jenis konten yang tidak terbatas, jangkauan khalayak, sifat global dari komunikasi. Mengakses tentang karya-karya yang dirilis oleh musisi, tetapi juga informasi yang berkaitan dengan musisi. Dari segi personal, informsi mengenai konser, serta sponsorship yang dilakukan oleh sang musisi. Untuk social media marketing akun media sosial yang digunakan Adhitia Sofyan yaitu Instagram dengan nama akun Adhitiasofyan, twitter dengan nama akun @ Adhitiasofyan dan Youtube dengan nama akun Adhitia Sofyan. pemasaran yang dilakukan melalui media sosial yang aktif hanya instagram.

Jika dihubungkan dengan penelitian ini, yang menjadi media baruialah media social (Instagram, Youtube, Spotify) memberikan akses bagi khalayak sebagai media komunikasi, informasi, dan fasilitas dalam melakukan promosi. Promosi yang menekankan pada pemberitahuan informasi tentang sebuah karya musik maupun merchandise dari sebuah musisi indie tersebut melalui jenis strategi marketing, yaitu mobile marketing, continuous marketing, visual marketing, digital marketing dan 
content marketing.

Melalui analisis data yang telah dilakukan oleh peneliti tentang strategi pemasaran yang dilakukan Adhitia Sofyan di Industri Musik Indonesia, peneliti dapat menjelaskan dengan lengkap mengenai pemasaran dan juga branding dari Adhitia Sofyan. Salah satu data yang menurut peneliti sangat penting adalah data yang di dapat pada saat melakukan wawancara dengan manajer dari Adhitia Sofyan. Setelah wawancara tersebut dilakukan, peneliti mendapat jawaban yang cukup memuaskan, karena dijelaskan secara detail bagaimana tim dari Adhitia Sofyan melakukan branding, serta melihat cangkupan luas Industri Musik di Indonesia saat ini.

Mungkin hal pertama yang dapat dijelaskan adalah perbedaan dari label rekaman indie dengan major label. Di era sekarang ini, hal yang paling terlihat dari kontrak kedua belah pihak. Selain itu juga , artis memproduksi karya musiknya sendiri secara independen, atau diproduksi melalui label rekaman komersil independen.

\section{Simpulan}

Sesuai dengan rumusan masalah dan juga tujuan dari penelitian yang telah dijabarkan oleh penulis, penelitian ini ingin menunjukan bagaimana strategi musisi indie dalam melakukan pemasaran di industri musik Indonesia. Dapat disimpulkan sebagai berikut:

1. Dalam analisis ini Adhitia Sofyan memfokuskan pemasarannya pada target pasar yang sudah dimiliki. Atau lebih tepatnya, tim dari Adhitia Sofyan sangat memfokuskan Segmentasi,Targeting,Positioning (STP). Karena hal tersebut yang sangat menjadi pedoman dalam pemasaran musisi indie yang dilakukan oleh manajemen,

2. Label Indie dan Major Label memiliki perbedaan yang cukup terlihat jelas. Dari analisis dan data yang dikumpulkan oleh peneliti, dapat disimpulkan bahwa, musisi lebih suka kebebasan, oleh karena itu banyak musisi yang memilih jalur indie. Karena di major label memiliki banyak tuntutan serta kontrak yang membuat musisi tidak dapat mengeksplor dirinya serta karyanya karena banyaknya tuntutan dari label.

\section{Ucapan Terima Kasih}

Penulis mengucapkan terima kasih yang sebesar-besarnya kepada semua pihak yang telah membantu penulis selama melakukan penelitian ini. Terima kasih atas dukungan yang telah diberikan Universitas Tarumanagara dalam proses pelaksanaan penelitian.

\section{Daftar Pustaka}

Basu, Swastha, \& Irawan. (2001). Manajemen Pemasaran Modern. Yogyakarta: Liberty.

Kotler, Philip. (2005). Manajemen Pemasaran. Jilid 1 dan 2. Jakarta: PT Indeks Kelompok Gramedia.

Kotler, Philip, \& Keller, Kevin. (2009). Manajemen Pemasaran, Edisi 13, Jilid 1, Edisi Bahasa Indonesia. Jakarta: Erlangga.

McQuail, Denis. (2011). Teori Komunikasi Massa Edisi 6. Jakarta: Salemba. 